\title{
Education Expenditure-Led Growth: Evidence from Nigeria (1980-2018)
}

\author{
Olukemi I. Lawanson ${ }^{1}$, Dominic I. Umar ${ }^{1}$ \\ ${ }^{1}$ Department of Economics, University of Lagos, Nigeria \\ Correspondence: Dominic I. Umar, Department of Economics, University of Lagos, Nigeria.
}

Received: January 19, 2020

Accepted: February 14, 2020

Online Published: February 26, 2020

doi:10.5539/ibr.v13n3p133

URL: https://doi.org/10.5539/ibr.v13n3p133

\begin{abstract}
This study examines the belief that education fosters economic growth by analyzing the impact of Government education expenditures at different levels on economic growth using Nigerian data for the period 1980-2018. Time series econometrics tests like Unit Root, cointegration, Error Correction Model and Granger Causality were employed to test the hypothesis of education expenditure-led growth strategy. The outcomes of the studies showed that that there is cointegration between total government education expenditures, primary, secondary and tertiary education expenditure and economic growth. The outcomes of the study also revealed that all levels of education expenditure contribute to economic growth positively (tertiary education exerting more positive impact) and are statistically significant (except primary education expenditure that is not significant) at 5\% level. The study equally revealed bi-directional causality between $t$ all levels public expenditure on education and economic growth. The study therefore, recommends improved funding for education at all levels given their interconnections. It also recommends that funding of primary education should by supported Federal Government as weak primary school funding will impact on quality of pupils that graduate to secondary school. Again policies aimed at diversifying and broadening the Nigerian economy be rekindled as economic growth have the potential of increasing education spending.
\end{abstract}

Keywords: education expenditure, economic growth, Nigeria

\section{Jel Classification: I25, O47, 055}

\section{Introduction.}

One major concern for developing economies in growth literature is the attainment of development-induced growth that will address the myriad development challenges such as poverty, unemployment, and human development deficiency confronting developing countries, including Nigeria. More so, issues of growth-induced factors have prominently featured in economic discussion empirically. To address this concern, studies like Okorie (2014), Olokoyo (2012), Ugochukwu and Chinyere (2013), and Oyelekan et al. (2015) emphasized the roles of macroeconomic drivers like a domestic investment, capital formation, inflation, exchange rate, and foreign direct investment in promoting economic growth in Nigeria. Despite that such drivers are fundamental in promoting growth, the neglect of government expenditure on education by these studies could constitute a serious limitation and weakens their policy implications especially the role of education and indeed human capital development in fostering economic growth. Infact, Wang and Wong (2011), argued that the effectiveness of macroeconomic drivers of growth depends on the quality education.

Though the role of government expenditure on education in economic growth appears to have gained consensus among scholars, emanated empirical outcomes are mixed. These conflicting outcomes account for the contest and the debate on the impact of education expenditure on economic growth both theoretically and empirically. For instance, Solow (1956) in a neoclassical growth model though posited diminishing returns to physical accumulation, accorded physical capital as the leading force in economic growth. However, the augmented Solow growth model by Mankiw, Romer and Weil, (1992) and endogenous new growth theory by Romer, (1990) and Lucas, (1988) mainstreamed economic growth to be a function of human capital development in the quest to provide a solution to the limitation of the neoclassical growth theory. The classical economic theory, on the other hand, advocates non-government intervention in the economy, hence holds a lateral view on government intervention through expenditure on education. 
Empirically, a considerable amount of positive evidence on the effects of education on growth has been generated ( See Barro 2001; Petrakos et al. 2007; Lawanson 2009; Dauda 2010; Omojimite 2012; Mercan \& Sezer 2014, Grant 2017, Usman \& Adeyinka, 2019). On the other hand, investigations by Mitchell, (2005), Yildirim et al. (2011), Gisore, et al. (2014), Jaiyeoba (2015) and Iheanacho, (2016) among others are in sharp contrast with studies that validated positive education-growth nexus. Zivengwa (2012) suggested that what is worthy of note is the transmission channels through which education impacts growth. Considerable evidence indicates that what is critical in education-growth is not just the amount expended but the roles of corruption and inefficiency of the institution in education-growth analysis in Nigeria (Nwankwo 2014; Eguniobi 2013). In their submission, Glewwe \& Muralidharan (2016) opined that what is fundamental is the quality of education in growth and analysis. In contrast, Roser \& Ortiz-Ospina (2020) discoursed that the quality of education, however, depends on the amount invested in Education. It is, therefore, plausible to infer that the augment on whether or not education expenditure is beneficial to growth is rooted in the different theoretical philosophies and empirical outcomes. The varying results and positions that stemmed from the above theoretical and empirical studies make the impact of government education expenditure on growth a subject of continuous debate.

Despite the increasing debate spanning from theoretical and empirical dichotomies, one thing that is noteworthy and has featured prominently in growth disclosure is the reputation of education as a propelling force and an enabler of the effectiveness of other macroeconomic determinants of economic growth. As a critical component of human capital, education has the potential for making growth inclusive by widening the earning pool of the educated, increase productivity, wages, opportunities for better employment and general well-being of the people (Lawanson 2009; Dauda 2010). Intuitively, it can be argued based on the above submissions that education investment is a potent political tool in the fight against development challenges confronting developing countries (UNDP, 1990). More so, education has a direct positive correlation with health output, improve health and fecundity (Schultz, 1999 and 2002; Strauss and Thomas, 1995; Amakon, 2015; Umar, 2017). Education is also a catalyst in the adoption of new technologies in the production process (Mwangi and Kariuki, 2015).

Additionally, education is key to the actualisation of sustainable development directly and indirectly in developing countries (The United Nation2018). Furthermore, the competitiveness and trade relationships among countries are enhanced through increased and improved productivity due to investment in education (Paganetto and Scandizzo, 2003). These benefits have made investment in education a global policy thrust and a potent lubricant on the wheel of sustainable development vehicles, hence its inclusion in sustainable development goal number 4.

Notwithstanding these pivotal roles of education in economic growth amid the conflicting empirical outcomes on the impact of education expenditure by these studies, the questions that come to mind are: what is the actual effect of education expenditure on economic growth in Nigeria? Which level of education expenditure impact more on economic growth and in which direction? As affirmed by Grant (2017), unearthing the impact of level-specific education expenditure on growth is vital, given the view that level-specific education expenditures do not have the same magnitude of effects on economic growth. The real gain of education expenditure on economic growth could be better captured by examining the impact of the different level of education expenditure on economic growth. Therefore, this study besides contributing to the debate on the actual effect of education expenditure disaggregate government expenditure into different levels of education (primary, secondary and tertiary) to determine their impact on economic growth for effective education expenditure policies in Nigeria. This is an area yet to be covered extensively by existing studies (Lawanson, 2009; Dauda, 2010; Omojimite, 2012, among others). More so, it intends to examine the feedback effects of education-growth channels in Nigeria.

\section{Stylised Facts on Education Expenditure in Nigeria}

This section highlights the evolution of budgetary allocation to education in Nigeria and some selected countries in Africa and across the globe for comparative understanding and as well as the economic growth outcomes over the reviewed period. It further shows government spending at different levels of education. Notwithstanding the apparent importance of education in economic growth, the revelation shows that the proportion of public expenditure on education in developing countries might be insufficient and a source of worry to address the development hiccups. A trend and comparative x-ray show no remarkable improvement as other countries have made concerted efforts to increase education spending than Nigeria in the face of increasing annual budget. In Nigeria, education spending as a ratio of gross domestic product (GDP) averaged 5.64\% between 1986 and 1990, compared to 5.84\% between 1999 and 2015. As a percentage of total government expenditure, the amount expended on education average was 6.98\% (CBN, 2015; FOS, 2016). 
Comparatively, stark realities show sharp contrast with other developing countries. Between 1980 and 2015, developing countries spent on the average $11.7 \%$ and $16.3 \%$ of their total annual budget on education, respectively. Ghana spends an average of $20 \%$ of its total expenditure on education yearly. In 2012, Ghana allocated 36.7\% of its budget to education. Between 1980 and 2015, Botswana spent 21 per cent of her expenditure on education, Burundi, 15\% Ivory Coast 20\% Malaysia, 19; Kenya, 20 per cent; Uganda, 15 per cent; and Nigeria, 8.70 per cent (CBN, 2015, World Bank, 2016). The neglect of education in the national budget could have a negative implication for the standard of education, health and education outcome in Nigeria, unlike in the other developed economies.

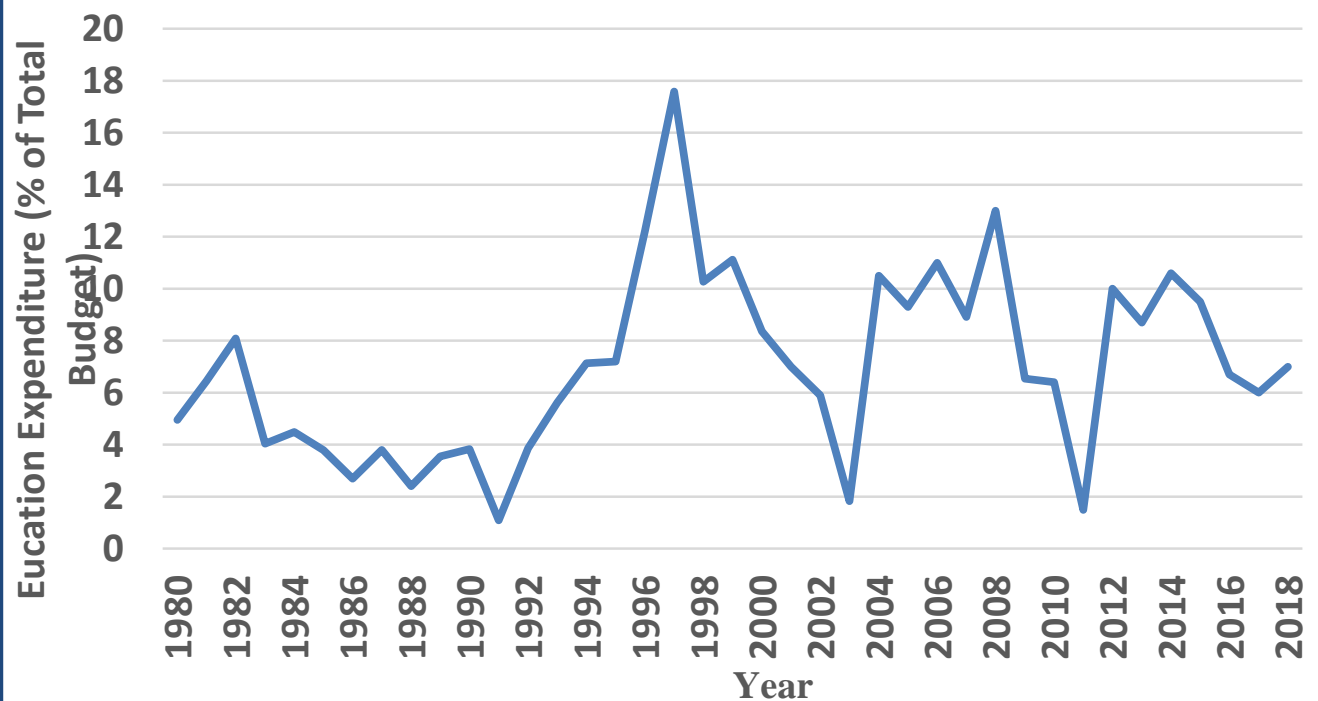

Figure 1. Government Expenditure on Education as a Percentage of Total Budget in Nigeria (1980-2018)

Source: Author’s Computation, 2019 from Central Bank of Nigeria (2019) Statistical Bulletin.

From fig 1, expenditure on education between 1980 and 2015 has been inconsistent and fluctuating with an average of $6.98 \%$ being spent on education. Except in 1997 when the amount spent was above 16\%, spending on education remained consistently low. 


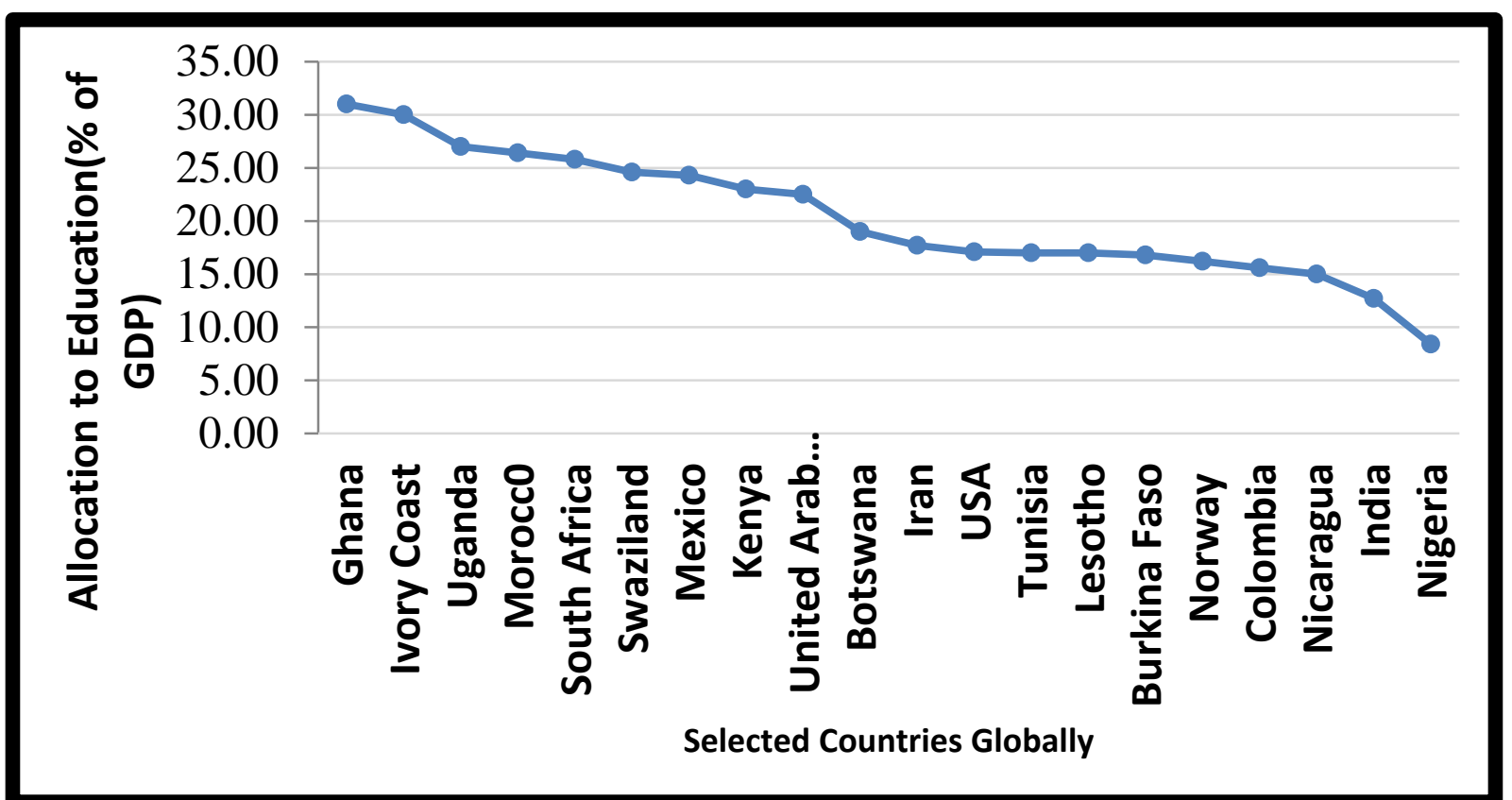

Figure 2. Allocation to Education (\% of GDP) in 2018: Selected Countries Globally

Source: Author's Computation, 2018 from World Data (2018)

Fig 2 shows expenditure on education as a percentage of GPD for some selected countries across the globe in descending order from left to right. Out of the selected 20 countries, Nigeria's allocation for education is the least with $8.4 \%$ in 2012. All the selected African countries are doing better than Nigeria with Ghana, having the highest allocation (31\% of GDP), followed by Ivory Coast (30\% 0f GDP), Uganda (27\% of GDP) and Morocco with $26.40 \%$ of GDP). The low level of human development in Nigeria is a function of government commitment to education.
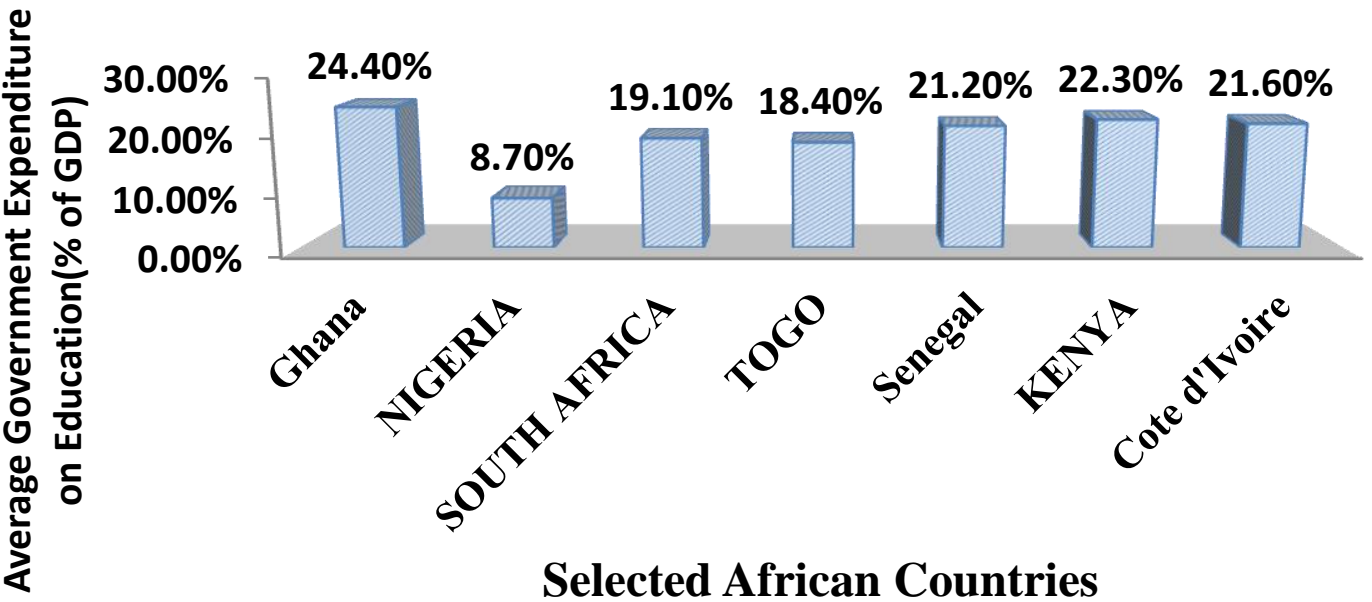

Selected African Countries

Figure 3. Average Government Expenditure on education (\% of GDP) for some selected African Countries 2005-2018

Source: Authors 'computation, (2018) from CBN Statistical bulletin and WDI (2018)

Fig 3 shows government expenditure on education as a percentage of GDP for some selected African countries. 
Nigeria is the least performer in terms of allocation to education when compared with the selected African countries. On 11 years' average, Nigeria's commitment to Education $(8.7 \%)$ is ranked the least whereas Ghana is the highest with $24.4 \%$ followed by Kenya(22.30\%), Cote d'Ivoire(21.60\%), and Senegal (21.20\%).

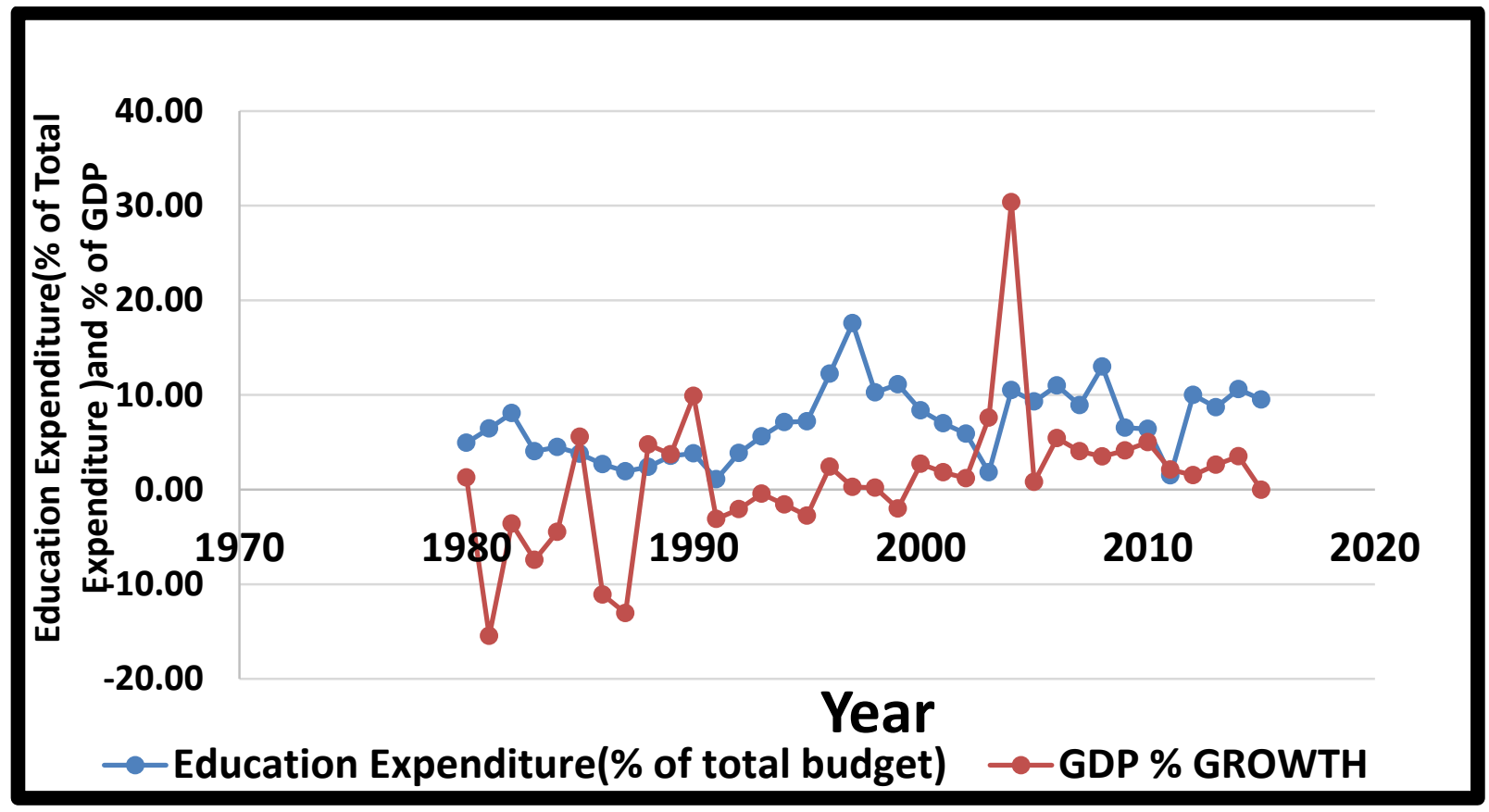

Figure 4. Education Expenditure (\% of Total Expenditure) and Percentage GDP Growth in Nigeria 1980-2018 Source: Authors 'computation (2018) from CBN Statistical bulletin and WDI (2018)

Fig 4 shows the trend in government expenditure and GDP growth in Nigeria between 1980 to 2018. The inconsistent feature of education spending may have reflected in the fluctuating growth in GDP. The Negative growth in the earlier 80s and 2015 may not be unconnected with the resultant effect of fall in oil price and recent economic recession respectively. Besides, the impact of high-level corruption in the system, as well as inefficiency in the institution, may have accounted for the poor performance of education expenditure on economic growth in Nigeria (See Nwankwo 2014)

Disaggregating education expenditure into different tiers reveals which tier receives more attention and where policy needs to be reinforced towards increasing spending. This is depicted in figure V. 


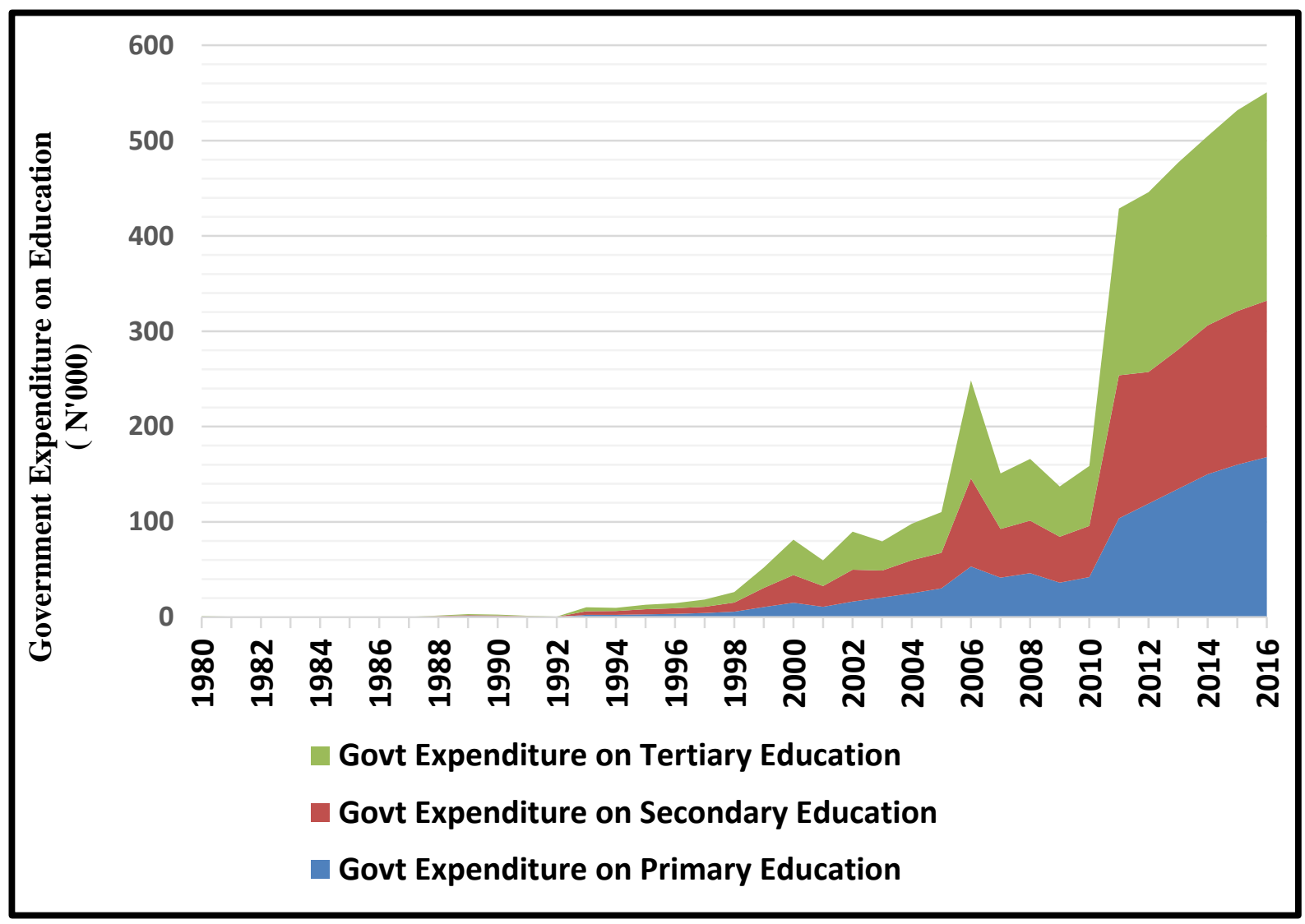

Figure 5. Government Expenditure among Primary, Secondary and Tertiary Education in Nigeria in Millions (1980-2016)

Source: Author's Computation, 2018 from the Federal Ministry of Education's data.

Despite the strategic importance of tertiary education in human capital development and stimulating growth, available data shows that the tertiary tier receives annually an amount a little above other levels of education.

\subsection{The Transmission Channels of Different Levels of Education to Economic Growth}

As stated by Zivengwa (2012), what is critical is not just the causal relationship between education and economic growth, but the routes education passed to economic growth. Below illustration tends to capture the channels which education-specific level could impact economic growth.

Figure VI shows the various channels which education at different levels could influence economic growth. A sizeable amount of evidence of the effects of primary education on economic growth exists, especially for those in agriculture. Primary education provides the underlying cognitive skills which are vital in the learning process and could affect the economic growth within the endogenous paradigm (see Loening 2005: Grant 2017). Primary education has the potential to increase output. It enhances employment prospect, especially small scale businesses and agriculture, which account for $85 \%$ of employment in Nigeria as well as increase income, especially for rural farmers (Shettima, 2017).

Secondary education provides the basis for improved skills, which impacts on the productivity level, improved employment and income earnings. Besides, secondary school leavers have better health education and awareness, hence more health outcomes. Tertiary education could impact on the level of economic growth via teaching, research and development, and service level. These key components are strategic to the economic performance of any nation (see Oketch et al. 2014).

These pathways have multiplier impact by enhancing the quality of the institutions, increased graduates' earnings, and improves productivity and efficiency of workers, improves health outcomes, facilitate research and development with a significant spillover effect in terms of transfer of technology and through capability improvement. More so, the quality of institutions is a very significant channel through which tertiary education 
impacts economic growth. The quality of institutions, especially law and order allows effective and efficient utilisation of education expenditure by curbing corruption (Peluso\& Veriani 2011). These channels are very significant to economic growth.

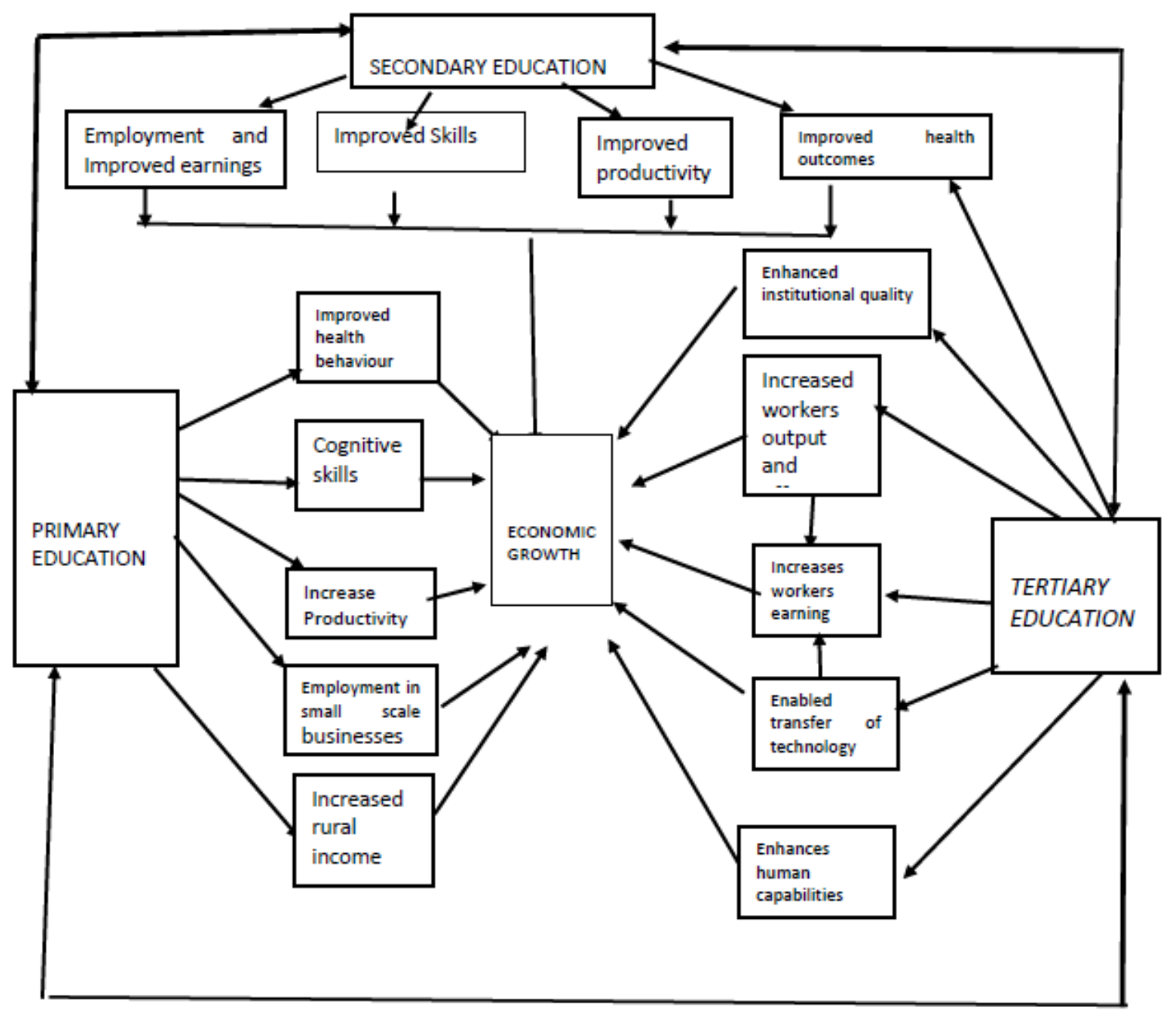

Figure 6. Channels which Levels of Education could Impact Growth

Source: The Author, 2019

In sum, the different levels of education are interconnected and dependent, and their interplay could have a strong influence on economic growth. Given the symbiotic relationships among them, policy action in terms of the allocated amount should not be mutually exclusive.

\section{Theoretical and Empirical Review of Literatures.}

Theoretical and empirical studies have focused more on the relationship between investment in education (human capital) and economic growth especially in the mid-1980s because of the inadequacy of the neoclassical growth theory in attributing growth principally to physical capital. This inadequacy has led to a quest among scholars seeking an explanation to the long-run drivers of economic growth. The neoclassical theory assumed diminishing returns to capital accumulation in their steady-state and zero per capita income growth. This was a stumbling block in neoclassical growth framework, hence the pursuit of economic growth theory that accounts for this limitation- that is, economic growth theory which emphasised human capital (not subject to diminishing returns) in the growth process.

Economic growth theory which emphasised economic growth-education investment nexus is rooted in the endogenous growth theory (Romer 1986, 1990 and Lucas 1988, among others). In its submission, Romer (1986) acknowledged that the economic growth rate is driven by technological change catalysed by human capital, 
hence the need for human capital accumulation. Comparatively, Romer's endogenous growth model differs from the neoclassical because he acknowledged the role of technological change and human capital in growth process unlike the neoclassical, which places growth solely in the hand of technological change.

In the attempt to deals with the limiting assumptions of diminishing returns to the capital of the neoclassical paradigm, Romer advocates that human capital should be treated as capital good which is subject to increasing marginal productivity since human investment capital can generate positive externalities for the entire economy. Therefore, endogenous growth model depends on technological changes and human capital. It advocates for measures aimed at stimulating economic growth and development. One of such measures of government spending on education can help to boost economic growth. Similarly, Gupta and Chakraborty (2004) in a dual economy analysis, emphasised that human capital development is fundamental for economic growth to take place. The dual relationship exists between the rich and the poor in the form of capital accumulation mechanism. Just as the rich allocate more time in accumulating knowledge for production, they expend more time in training the poor.

Empirically, a plethora of studies have examined education expenditure-growth nexus with different outcomes. While some empirical findings concluded that economic growth responds positively, others are on the contrary. For instance, Lawanson (2009) through the methodological lens of ordinary least square analysed the contribution of human capital on economic growth in Nigeria using time series data covering 1983 to 2007. The outcomes of the study gave captivating evidence that government expenditure on education was statistically significant and had a positive impact on economic growth in Nigeria. Dauda (2010), through the application of co-integration techniques, examined the relationship between government expenditure on education and economic growth using time series data covering 31 years (1977-2007). The result revealed an inherent significant and positive relationship between economic growth and education spending in Nigeria. This Collaborated earlier study by Dauda, (2009) that economic growth is positively dependent on education expenditure in which different techniques of Johansen co-integration and error correction methods were employed covering the same period of 1977 to 2007.

A cross-country study of three African countries (Botswana, Malawi and Uganda) Al-Samarrai (2003), revealed that the nexus between public spending and primary school access is weak. As a result, per-pupil education spending reduced at the time when access education was on the increase. The inverse nexus between access to education and spending in Malawi and Uganda is apparent, partly due to significant change in educational services offered over that period. Therefore, improving access to the same type of schools and intensity of use cannot be achieved through reductions in per-pupil expenditure.

Additionally, Gylfason and Zoega (2003), x-rayed the effects of gross secondary-school enrolment, public education expenditure relative to the level of national income and expected time of schooling for girls and economic growth among different countries. The research showed that these measures of education directly correlate to income equality. It was also discovered that an increase in education spending directly spur economic growth and indirectly by increasing social fairness and bond. Improvement in education due to an increase in public expenditure can promote economic growth and bridge inequality gap. The study concludes that education spending encourages economic growth not only by increasing and improving human capital but also as a catalyst for physical and social capital.

Bakare (2006), investigated the nexus between economic growth and human capital investment in Nigeria with the aid of vector autoregressive error corrections mechanism. The empirical study found that there is a significant positive nexus between investments in human capital and economic growth in Nigeria. It was further revealed that when investment in human capital declined by 1 per cent, economic growth declined by $48.1 \%$ between 1970 and 2000. More so, Babatunde and Adefabi (2005) investigated the long-run relationship between education expenditure and economic growth performance in Nigeria between 1970 and 2003 through the application of Johansen co-integration technique and vector error correction methodology. Their findings reveal that the Johansen co-integration result establishes a long-run positive relationship between education and economic growth Findings of the study suggest that a well-educated labour force contribute significantly to economic growth.

In contrast, Jaiyeoba (2015) investigated the relationships between human capital investment and economic growth in Nigeria between 1982-2011. The study which employed the ordinary least square method found that a long-run relationship existed between human capital investment and economic growth. The study further revealed an inverse relationship among government expenditure, primary enrolment rate and economic growth. Gisore et al. (2014) examined the implication of government expenditure on economic growth in East Africa by 
disaggregating government expenditure from 1980 to 2010 using a balanced fixed panel model. Among the variable employed, education expenditure was found to have an insignificant and negative impact on economic growth. Similarly, Iheanacho (2016) examined the short-run and long-run effects of government education expenditure on economic growth in Nigeria using data between 1988 and 2014. The study revealed a negative relationship between education expenditure and economic growth in Nigeria when government expenditure on education was disaggregated into capital and recurrent expenditure.

In a study on the impact of public spending on education on economic growth in Turkey using Causality approach, Yildirim et al. (2011) found a unidirectional flow between economic growth and education spending in Turkey. The study discovered that causality flows from economic growth to education spending and not from education spending to economic growth. Based on this, they concluded that public education spending does not contribute to economic growth in Turkey. Again, Mitchell (2005) examined how government spending (including spending on education) in developed countries influence economic performance. It was discovered that reduction in government expenditure as a proportion of national output had a better economic performance than those that increase their spending on education hence reduction in government spending will increase economic growth and guarantee economic competitiveness.

\section{Theoretical Framework and Methodology}

The theoretical foundation of this study is anchored on human capital induced-growth by Romer (1986 and The study, however, extends the frontier by decomposing government expenditure on education into different components. The disaggregation of government expenditure on education into primary, secondary and tertiary levels provides a more reasonable and comprehensive apparatus for investigating the role of government expenditure on education in economic performance. According to Romer, the source of divergence in economic performance and growth rate across countries is human capital. Moreover, technology and information which are end products of discoveries are the spillover effects of deliberate human efforts (Romer, 1986, 1994).

\subsection{Model Specification}

From the endogenous perspective, Romer (1986, and 1990), Lawanson (2009) and Dauda (2010) defined the transmission mechanisms through human capital flows to economic growth. Human capital plays a direct impact on economic growth as an independent factor as well as an indirect role as it acts as a catalyst in technological change with portent growth implication. The standard Cobb-Douglas production provides the stage to appreciate the role of education (human capital) in output determination. The production function could be specified as

$$
Y_{t}=A K_{t}^{m} L_{t}^{n}
$$

Where $0 \leq \mathrm{m}$ and $\mathrm{n} \leq 1 \mathrm{Y}_{\mathrm{t}}=$ output, $\mathrm{K}_{\mathrm{t}}=$ Physical Capital, $\mathrm{L}=$ Labour and $\mathrm{A}=$ is the technological factor which from the neoclassical perspective is the brain behind long-run growth and is determined outside the economy as opposed to internal factors (endogenous strength) and suffers from marginal productivity decline as its unit increases. It equally hypothesized convergence for the economy; however, to determine the catch-up effect, we

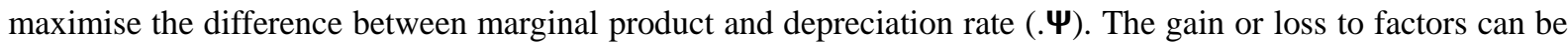
determined from equation (2)

$$
r=a A K_{t}^{m-1} L_{t}^{n}-\Psi
$$

The growth rate of labour is determined outside the model as $w$, and this must be satisfied for the value of $r$ to remain unchanged. Differentiating equation 2 we have

$$
(d K / d) t / K=n w /(1-m)
$$

Equation (3) shows the steady-state growth rate of capital stock. If the rate of capital stock is low relative to the population, there will be a higher rate of returns leading to a higher capital growth rate. As capital accumulates, the rate of return will fall to a steady-state. In other words, developing countries or low-income economies with low per capita stock and income per head will catch up with the advanced as it tends to grow faster.

However, Lucas (1988), Romer(1986, 1990) presented a different theoretical paradigm when human capital was eulogised as providing the fluid in the growth process by endogenising the technology factor. This is depicted below.

$$
A_{t}=\alpha H_{t}^{p}
$$




$$
0<p<1
$$

Where; $\mathrm{H}_{\mathrm{t}}$ is the amount of human capital needed to produce economic value. If $\mathrm{H}_{t}$ increases by $1 \%, \mathrm{~A}_{\mathrm{t}}$ will increase by $\mathrm{p} \%$.

If labour is expended between the production of physical output by $q \mathrm{~L}$ and human capital production by (1-q) L, then our standard Cobb-Douglas production function in equation 1 becomes,

$$
Y_{-} t=\pi K_{t}^{m} H_{t}^{p}\left(p L_{t}\right)^{n}
$$

Where $\mathrm{Y}_{\mathrm{t}}=$ output, $\boldsymbol{\pi}=$ total factor productivity (TFP), $\mathrm{K}=$ physical capital and $\mathrm{H}_{\mathrm{t}}$ is the human capital component in production function that accounts for technological change and enhances labour productivity. The human capital is defined by total government expenditure in education (TED) which is further decomposed into primary education expenditure(PEE), secondary education expenditure (SEE) and tertiary education expenditure, a deviation from previous studies (see Lawanson, 2009 and Dauda, 2010). In this model, growth is possible as long as there is continuous investment in human capital through education expenditure. This implies that there is no diminishing return in the production of human capital. Taking government education expenditure, primary, secondary and tertiary education expenditure as well as total government expenditure on health and gross capital formation as variables that determine output growth, our growth model in line with the Romer (1986, and 1990) (endogenous theory) and empirical works of Lawanson, (2009); Dauda, (2010) and Umar, (2017) is specified as:

$$
Z=\phi_{0}+\aleph_{1} Z(-1)+Ж_{2} T E D_{t}+Ж_{3} T E H_{t}+\aleph_{4} G C F_{t}+Ж_{5} P E E+\aleph_{6} S E E+\aleph_{7} T E E+\mu
$$

Where: $\aleph_{1}, \aleph_{2}, \aleph_{3}, \aleph_{4}, \aleph_{5}, \aleph_{6}$ and $\aleph_{7}>0$

$Z=$ Real PerCapita Gross Domestic Product (a proxy for economic growth), (Z-1)=Initial Real Per Capita GDP, $T E D=$ Government Total Expenditure on Education in Nigeria, $T E H=$ Government Expenditure on Health a control variable in this study, $G C F=$ Gross Capital Formation (a proxy for capital), $P E E$ = Primary school education expenditure, $S E E$ =Secondary school education expenditure and $T E E$ = Tertiary education expenditure. $\beta_{0}=$ Constant term, whereas $\aleph_{1}, \aleph_{2}, \aleph_{3}, \aleph_{4}, \aleph_{5}, \aleph_{6}$ and $\aleph_{7}$ are the different elasticities of the independent variables and are expected to have a positive sign, and $\mu=$ Error term which account for non-included variables.

\subsection{Unit root, Co-integration and Error Correlation Model}

Given that a time series data in an economic model is characterised by non-stationary, it imperative to carry out a unit root and Co-integration analysis to determine the time series properties of the model and also ascertain whether or not the variables are Co-integrated. The unit root test is conducted using the Augmented Dickey-Fuller (ADF) and Philip Perron (PP) to verify the stationary of the model across the sample in the period under review whereas co-integrated analysis is carried using Johansen's Cointegration Test determine the order of co-integration. Cointegrated variables may result in spurious regression which will make the analysis meaningless and the result of no policy implication. However, if the stochastic trends cancel out, then the variables are co-integrated, which then warrant an error correlation model (ECM).

\subsection{Error Correction Model}

This method of analysis was developed by Sargan (1984) and later advanced by Engle and Granger (1987). It is a method by which short-run and long-run behaviours of economic variables are reconciled. One famous theorem in the reconciliation of the actions of these economic variables is the Representation theorem by Engle and Granger (1987). This theorem acknowledged that any cointegrated time series data has representation that corrects the error which accounts for the short-run adjustment contrivance. This study used the ECM method of analysis because the error correlation model captures short and long-run relationships between the dependent and independents variables in the model. Besides, it addresses the problems of serial correlation and endogeneity, which are usually present in time-series data, unlike the ordinary least square method of analysis (Shrestha \& Bhatta 2017).

The long-run linear relationship among the variables is thus presented below. Equation 6 is transformed into an error correlation model.

$$
\Delta \ln Z_{t}=\aleph_{0}+Ж_{1} Z(-1)+\aleph_{2} \Delta \ln T E D_{t}+Ж_{3} \Delta \ln T E H_{t}+\aleph_{4} \Delta \ln G C F_{t}
$$




$$
\begin{aligned}
& +Ж_{5} \Delta P E E+Ж_{6} \Delta S E E+Ж_{7} \Delta T E E+Ж_{8} E C T_{1 t-1}+\gamma_{1 t} \\
& \Delta \ln T E D_{t}=\beta_{0}+\beta_{1} Z(-1)+\beta_{2} \Delta \ln Z_{t}+\beta_{3} \Delta \ln T E H_{t}+\beta_{4} \Delta \ln G C F_{t} \\
& +\beta_{5} \Delta P E E+\beta_{6} \Delta S E E+\beta_{7} \Delta T E E+\beta_{8} E C T_{2 t-1}+\gamma_{2 t} \\
& \Delta \operatorname{lnTEH_{t}}= \\
& \alpha_{0}+\alpha_{1} Z(-1)+\alpha_{2} \Delta \ln Z_{t}+\alpha_{3} \Delta \operatorname{lnTED_{t}}+\alpha_{4} \Delta l n G C F_{t}+\alpha_{5} \Delta P E E+\alpha_{6} \Delta S E E+\alpha_{7} \Delta T E E+\alpha_{8} E C T_{3 t-1}+\gamma_{3 t} \\
& \Delta \operatorname{lnGCF} F_{t}=\pi_{0}+\pi_{1} Z(-1)+\pi_{2} \Delta \ln Z_{t}+\pi_{3} \Delta \operatorname{lnTED_{t}}+\pi_{4} \Delta \ln T E H_{t}+\pi_{5} \Delta P E E+\pi_{6} \Delta S E E \\
& +\pi_{7} \Delta T E E+\pi_{8} E C T_{4 t-1}+\gamma_{4 t} \\
& \Delta \ln P E E_{t}=\Omega_{0}+\Omega_{1} Z(-1)+\Omega_{2} \Delta \ln Z_{t}+\Omega_{3} \Delta \ln T E D_{t}+\Omega_{4} \Delta \ln T E H_{t}+\Omega_{5} \Delta G C F+\Omega_{6} \Delta S E E \\
& +\Omega_{7} \Delta T E E+\Omega_{8} E C T_{5 t-1}+\gamma_{5 t} \\
& \Delta \operatorname{lnSEE_{t}}=\mu_{0}+\mu_{1} Z(-1)+\mu_{2} \Delta \ln Z_{t}+\mu_{3} \Delta \ln T E D_{t}+\mu_{4} \Delta \ln T E H_{t} \\
& +\mu_{5} \Delta G C F+\mu_{6} \Delta P E E+\mu_{7} \Delta T E E+\mu_{8} E C T_{6 t-1}+\gamma_{6 t} \\
& \Delta \operatorname{lnTEE_{t}}=\theta_{0}+\Theta_{1} Z(-1)+\Theta_{2} \Delta \ln Z_{t}+\Theta_{3} \Delta \ln T E D_{t}+\theta_{4} \Delta \ln T E H_{t} \\
& +\Theta_{5} \Delta G C F+\theta_{6} \Delta P E E+\theta_{7} \Delta S E E+\Theta_{8} E C T_{7 t-1}+\gamma_{7 t}
\end{aligned}
$$

Where: $\Delta=$ the first difference parameter (i.e. $\Delta \ln Z_{t}=\ln Z_{t}-\ln Z_{t-1}, \Delta \ln T E D_{t}=\ln T E D_{t}-\ln T E D_{t-1}$, $\left.\Delta \operatorname{lnTEH_{t}}=\ln T E H_{t}-\operatorname{lnTEH}_{t-1}, \ldots \ldots \ldots \ldots \ldots, \Delta \ln T E E_{t}=\ln T E E_{t}-\ln T E E_{t-1}\right), \mathrm{t}=$ time movement, the coefficients of ECT account for the degree of convergence of the models to equilibrium after deviations from their long-run positions whereas $\gamma_{1 t} \ldots \ldots, \gamma_{7 t}$ are the white noise error terms. The values of the ECT are expected to be negative and statistically significant.

\subsection{Granger Causality Tests}

One problem usually associated with economic growth- education expenditure analysis is feedback effect. Public expenditure on education could be endogenous; hence, the regression result could be misinterpreted because the estimated result is statistically(Granger, 1969). To ascertain this, the proposed Granger Causality test by Granger (1969) and Sims (1972) are used to test whether education expenditure is useful in forecasting economic growth and vice-versa. Generally, a time series $P$ is said to Granger-cause another time series $Q$ if it can be revealed that the series $\mathrm{P}$ values provide information that is statistically significant about the future values of series $\mathrm{Q}$ if not, $\mathrm{P}$ does not Granger Cause Q.

The causal relationship between variables can either be uni-directional or bi-directional. The null hypothesis of no causality is tested against the alternative hypothesis of causality between two variables. In a two-variable model $\mathrm{P}$ and $\mathrm{Q}$, the following two equations are specified

$$
\begin{aligned}
& . Q_{t}=\sum_{k=1}^{n} \delta_{k} P_{t-1}+\sum_{k=1}^{n} \beta_{k} Q_{t-1}+U_{1 t} \\
& P_{t}=\sum_{k=1}^{n} \Upsilon_{k} Q_{t-1}+\sum_{k=1}^{n} \lambda_{k} P_{t-1}+U_{2 t}
\end{aligned}
$$

Where $1 i u$ and $2 i u$ are serially uncorrelated random disturbances with zero mean. If P Granger causes $\mathrm{Q} ; H_{0}$ : $\delta_{1}=\delta_{2}=\delta_{3}-----\delta_{n}=0$ is rejected against the alternative hypothesis. This means that there is strong evidence to accept the alternative hypothesis, $H_{1}$. In the same way, if Q Granger causes P; $H_{0}: \lambda_{1}=\lambda_{2}=\lambda_{3}------\lambda_{n}=0$ is rejected against the alternative hypothesis. Therefore, we accept the alternative hypothesis, $H_{1}$

\subsection{Endogeneity Issues between Economic Growth and Human Capital Variables}

The relationship between dependent and explanatory variables is the fact that many explanatory variables could be endogenous; that is, their impact on economic and are influenced by economic growth as often shown by the 
bi-causal relationships. The implication is that it leads to estimation bias. This is predominantly the case with human capital variables: To address this problem, this study follows the recommendations by researchers to reduce the impact of the problem using an instrumental variable. However, this does not address the cultural and historical antecedents which differ across countries that influence economic growth and initial education spending which could be correlated with the stochastic or error term (Glewwe et al. 2014).

\subsection{Structural Stability test of the Coefficients}

It is also expedient to verify if the coefficients of the model are structurally stable over the period or not especially when it is uncertain as per the exact time of structural change (see Brown et al. 1975; Galpins and Hawkins, 1984). Two tests are carried using recursive residuals. These are the cumulative sum (CUSUM test) and the cumulative sum of square (CUSUMSQ) test. No matter the period under consideration, if the coefficient remains unchanged, we accept the null hypothesis of no structural change. However, variation in the coefficient leads to rejection of the null hypothesis. One problem with the CUSUM test is that it is less powerful, and the null hypothesis could be accepted even when there is structural change. Thus, the CUSUMSQ which is more potent though does not show when structural occurs is used to complement the CUSUM test (Brown et al. 1975)

\section{Presentation and Analysis of Results}

This study makes use of Nigerian time series secondary data from 1980 to 2018 from CBN, National Bureau of Statistics and World Bank Development Indicators. One of the problems of time series data is non-stationary. Trends have the potentials of causing regression results spurious and also making t-statistics results difficult to interpret. Therefore, the data need to be detrended to show an absolute change in value and to identify likely cyclical shift in line with Pedroni's (1999). This continues until stationary is reached by conducting unit root tests determine whether or not the series is stationary and at what levels and check for the order of co-integration.

Table 1. Augmented Dickey-Fuller (ADF) and Philip Perron Unit Root Tests

\begin{tabular}{|c|c|c|c|c|c|c|c|}
\hline \multirow{2}{*}{ Variables } & \multicolumn{2}{|l|}{ Augmented } & \multirow{2}{*}{$\begin{array}{r}\text { Critical } \\
\text { Value @ } \\
10 \%\end{array}$} & \multirow{2}{*}{$\begin{array}{r}\text { Philip } \\
\text { Perron } \\
\text { test } \\
\text { Statistics } \\
\end{array}$} & \multirow[b]{2}{*}{$\begin{array}{l}\text { Critical } \\
\text { Value@ 5\% }\end{array}$} & \multirow{2}{*}{$\begin{array}{r}\text { Critical } \\
\text { Value @ } \\
10 \%\end{array}$} & \multirow{2}{*}{ Stationary. } \\
\hline & $\begin{array}{l}\text { Dickey-Fuller } \\
\text { Test }\end{array}$ & $\begin{array}{l}\text { Critical } \\
\text { Value@ 5\% }\end{array}$ & & & & & \\
\hline RPCGDP & -5.132935 & -3.544284 & -3.204699 & -6.339792 & -2.843408 & -2.769132 & $\mathrm{I}(1)$ \\
\hline TED & -7.653143 & -2.948404 & -2.612874 & -9.345442 & -3.974524 & -2.610263 & $\mathrm{I}(1)$ \\
\hline TEH & -8.376134 & -2.948404 & -2.612874 & -9.229801 & -2.943427 & -2.85263 & $\mathrm{I}(1)$ \\
\hline GCF & -5.557846 & -2.948404 & -2.612874 & -6.339791 & -2.636534 & -2.610263 & $\mathrm{I}(1)$ \\
\hline PEE & -5.559316 & -3.846284 & -3.204699 & -4.842637 & -2.534563 & -2.813212 & $\mathrm{I}(1)$ \\
\hline SEE & -5.349727 & -3.657759 & -3.212361 & -8.155457 & -3.381352 & -2.610263 & $\mathrm{I}(1)$ \\
\hline TEE & -5.088726 & -3.657758 & -3.212361 & -7.243162 & -3.564423 & -2.713254 & $\mathrm{I}(1)$ \\
\hline
\end{tabular}

Author's Computation, 2019

Remarkably, the Augmented Dickey-Fuller (ADF) and Philip Perron tests in table 1 revealed that all the variables attained their orders of stationarity at difference 1 as they were de-trend.In other words, the variables (RPCGDP, TED, TEH, GCF, PEE, SEE and TEE) are integrated of order one. However, while differencing, vital long-run information might be lost. To overcome this problem, there is a need to find out whether or not the variables are cointegrated (Granger 1981). The cointegration test shows the possibility of long-run relationships among the variables. Based on the unit root results, the study checked if the variables are cointegrated and have long-run relationship in line with Granger (1981). To do this, the Johansen's Co-integrated test is conducted and results, as shown in the tables below.

Table 2. Unrestricted Cointegration Rank Test (Trace)

\begin{tabular}{|l|c|c|c|r|}
\hline Hypothesized & & Trace & 0.05 & Prob.** \\
\hline No. of CE(s) & Eigenvalue & Statistic & Critical Value & 0.0000 \\
\hline None ${ }^{*}$ & 0.836712 & 204.2580 & 150.5585 & 0.0008 \\
\hline At most 1 & 0.806979 & 140.8297 & 117.7082 & 0.0019 \\
\hline At most 2* & 0.804064 & 136.25627 & 115.8038 & 0.0034 \\
\hline At most 3* & 0.763404 & 120.38125 & 112.87610 & 0.2776 \\
\hline At most 4 & 0.371896 & 34.23964 & 42.91525 & 0.3464 \\
\hline At most 5 & 0.306019 & 17.96289 & 25.87211 & 0.5712 \\
\hline At most 6 & 0.137495 & 5.177012 & 12.51798 & \\
\hline
\end{tabular}


Authors Computation, 2019

Trace test indicates 4 cointegrating eqn(s) at the 0.05 level $*$ denotes rejection of the hypothesis at the 0.05 level **MacKinnon-Haug-Michelis (1999) p-values

Table 3. Unrestricted Cointegration Rank Test (Maximum Eigenvalue)

\begin{tabular}{lllll}
\hline $\begin{array}{l}\text { Hypothesized } \\
\text { No. of CE(s) }\end{array}$ & Eigenvalue & $\begin{array}{l}\text { Max-Eigen } \\
\text { Statistic }\end{array}$ & $\begin{array}{l}0.05 \\
\text { Critical Value }\end{array}$ & Prob.** \\
\hline None ${ }^{*}$ & 0.836712 & 63.42830 & 50.59985 & 0.0005 \\
At most 1 & 0.806979 & 57.57346 & 44.49720 & 0.0012 \\
At most 2* & 0.800064 & 55.87502 & 42.33101 & 0.0040 \\
At most 3* & 0.753404 & 53.14161 & 40.11832 & 0.0051 \\
At most 4 & 0.371896 & 16.27675 & 25.82321 & 0.5201 \\
At most 5 & 0.306019 & 12.78588 & 19.38704 & 0.3456 \\
At most 6 & 0.137495 & 5.177012 & 12.51798 & 0.5712 \\
\hline
\end{tabular}

Author's Computation, 2019

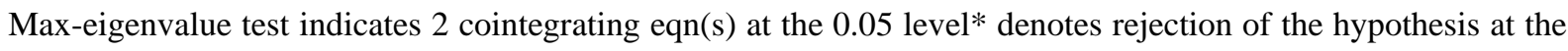
0.05 level

Table 2 and 3 present the Johansen co-integration test results and shown by the Trace and Maximum Eigenvalue. The outcomes by Trace test indicates that there are 4 co-integrating equations, likewise the Maximum Eigenvalue, implying that long-run relationships exist among the variables. Therefore, the null hypothesis of no co-integration among the variables should be rejected at one 5\% level of significance. Since the variables are co-integrated, there it is imperative to construct the Error Correction Model (ECM). This is depicted in Table IV.

The outcomes of the error correction model (ECM) is presented in Table IV. The lagged error correction term $\left(\mathrm{ECM}_{\mathrm{t}-1}\right)$ has the expected negative sign (-0.683147). It validated the existence of a long-run relationship between the dependent variable (RPCGDP) and the regressors (RPCGDP (-1) TED, TEH, GCF, PEE, SEE and TEE). The coefficient of the error term indicates that a speed adjustment of around - 0.683147 . This suggests that, following short-run disequilibrium or deviation, 68 per cent of the adjustment to the short-run takes place either by the market mechanism, government intervention or both.

In absolute term, not all variables are statistically significant. However, both the lag and current values of Total Expenditure on Education in Nigeria are statistically significant at both levels- 5 per cent and 10 per cent levels of significance respectively. In fact, except for the lag values of primary school education expenditure and gross capital formation, the values of all variables are statistically significant at 5 and $10 \%$ levels.

Besides, all the variables show the expected apriori signs except for gross capital formation both at both periods. The result indicates that any policy that will double the total expenditure on education in Nigeria will cause the economy to grow by $12.9 \%$ per cent. This is above the growth target rate of $4.8 \%$ set in the Economic Recovery and Growth Plan, 2018. This result is in line with Lawanson (2009), Dauda (2009), Grant (2017), Usman \& Adeyinka, (2019) and at variance, with empirical findings of Mitchell, (2005), Yildirim et al. (2011), Gisore, et al. (2014), Jaiyeoba (2015) and Iheanacho, (2016) This result underscores the importance of education in the economic growth of a nation, Nigeria inclusive.

Similarly, the results of the three-levels of education spending gave positive growth indications. The primary, secondary and tertiary education expenditures are positive in the current and lag periods though tertiary education expenditure had far-reaching implication for growth than secondary and primary education expenditure. However, only tertiary education expenditure is statistically significant. For instance, any economic policy that will double tertiary, secondary and primary education expenditures will increase economic growth by $11.1 \%, 3.9 \%$ and $1.3 \%$ respectively. The outcome of the tertiary education impact on economic growth conforms to Turruam et al., (2014) and accentuates the importance of tertiary education in economic growth. 
Table 4. Error Correction Model (ECM).

Dependent Variable: D(LNRPCGDP). Included observations: 31 after adjustments

\begin{tabular}{|c|c|c|c|c|}
\hline Variable & Coefficient & Std. Error & t-Statistic & Prob. \\
\hline $\mathrm{C}$ & 0.210021 & 2.016137 & $1.621037 *$ & 0.0083 \\
\hline $\mathrm{D}(\mathrm{LNRPCGDP}(-1))$ & 0.194819 & 3.245020 & $1.795117 *$ & 0.0032 \\
\hline D(LNTED) & 0.129896 & 0.922466 & $1.330723 *$ & 0.2019 \\
\hline $\mathrm{D}(\operatorname{LNTED}(-1))$ & 0.093441 & 0.722241 & $-0.604347 *$ & 0.5541 \\
\hline $\mathrm{D}(\mathrm{LNGCF})$ & -0.020798 & 0.020380 & $-1.020511 *$ & 0.3227 \\
\hline $\mathrm{D}(\mathrm{LNGCF}(-1))$ & -0.009312 & 0.018857 & $0.493856 * *$ & 0.6281 \\
\hline D(LNTEH) & 0.083552 & 0.067283 & $1.241798 *$ & 0.0322 \\
\hline D(LNTEH(-1)) & 0.037582 & 0.081391 & $0.561740 * *$ & 0.3505 \\
\hline $\mathrm{D}$ (LNPEE) & 0.013489 & 0.068990 & $0.225810 * *$ & 0.8211 \\
\hline $\mathrm{D}(\operatorname{LNPEE}(-1))$ & 0.028673 & 0.083148 & $0.344847 * *$ & 0.7347 \\
\hline D(LNSEE) & 0.039873 & 0.122477 & $-0.454174 * *$ & 0.0471 \\
\hline $\mathrm{D}(\operatorname{LNSEE}(-1))$ & 0.041160 & 0.133978 & $-1.501435^{*}$ & 0.1527 \\
\hline D(LNTEE) & 0.111579 & 0.118225 & $1.797943^{*}$ & 0.0232 \\
\hline $\mathrm{D}(\mathrm{LNTEE}(-1))$ & 0.168382 & 0.142198 & $1.184137 *$ & 0.2537 \\
\hline $\operatorname{ECM}(-1)$ & -0.683147 & 1.904532 & $-1.241784 *$ & 0.0322 \\
\hline$\overline{\mathrm{R} \text {-squared }}$ & 0.851070 & Mean dependent var & & 0.016219 \\
\hline Adjusted R-squared & -0.789243 & S.D. dependent var & & 0.066261 \\
\hline S.E. of regression & 0.067223 & Akaike info criterion & & -2.255251 \\
\hline Sum squared resid & 0.072303 & Schwarz criterion & & -1.561386 \\
\hline Log-likelihood & 49.95639 & Hannan-Quinn criteria. & & -2.029068 \\
\hline F-statistic & 93.939116 & Durbin-Watson stat & & 2.116668 \\
\hline Prob(F-statistic) & 0.000000 & & & \\
\hline
\end{tabular}

The above analysis was carried out at 5\% level of significance. T-statistics* Significance at $5 \%$ level and ** not significance at $5 \%$ level

Authors Computation, 2019.

Though both primary and secondary education expenditures are insignificant, they have the potential of stimulating economic growth positively as shown by the positive signs as they lay the foundation for quality tertiary education as well as educational outcomes with significant correlation with growth (Urhie, 2013). Their low impact could be as a result of low spending on primary and secondary education compared to the tertiary.

Total expenditure on health, the control variable in this study impact economic growth positively, and it is statistically significant at 5\% and $10 \%$ levels. For instance, any economic policy that will double the total health expenditure will impact economic growth positively by $8.3 \%$. This supports the empirical finding of Lorentzen et al. (2008) on the implication of health expenditure on economic growth. Health expenditure could help to improve the health status of the labour force, increase productivity, increase per capita output and economic well-being, Besides, improvement in health could have a beneficial impact on the economic growth as both are complementary (Umar 2017). As for gross capital formation, a proxy for capital, the outcome shows negative signs both in the previous and current periods but statistically significant only in the current period contrary to Shuabi and Ndidi(2015). Though capital exact negatively on economic growth directly in this study, it has the potential of impacting economic growth positively through human capital development according to capital human-induced growth by Romer $(1986 ; 1990)$

The R-squared (R2) of 0.851070, which measures the goodness of fit, indicates that the regressors explain $85 \%$ per cent of the systematic variation of the economic growth in Nigeria during the period of the study. And, it remains strong even after the adjustment for the degree of freedom to $78.9 \% \%$. Also, the overall F-statistic of 93.939116, which measures the overall statistical influence of the explanatory variables in explaining the dependent variable, with the corresponding probability value of 0.0000 , gives clear evidence that the equation is well fitted. That is, the explanatory variables are statistically significant. With the overall F-statistic indicating that the regressors are statistically significant.

Given that education expenditures or human capital development could also respond to the level of economic growth, the Pairwise Granger Causality test is carried out to determine the direction of causality. The result is presented in Table $\mathrm{V}$ below to show the direction of causality. 
Table 5. Pairwise Granger Causality Tests. Lag:7

\begin{tabular}{|c|c|c|c|}
\hline Null Hypothesis: & Obs & F-Statistic & Prob. \\
\hline PCGDP does not Granger Cause TED & 30 & 1.18687 & 0.0405 \\
\hline TED does not Granger Cause PCGDP & & 2.68607 & 0.0113 \\
\hline PEE does not Granger Cause PCGDP & 30 & 1.57241 & 0.0303 \\
\hline PCGDP does not Granger Cause PEE & & 2.82818 & 0.0249 \\
\hline SEE does not Granger Cause PCGDP & 30 & 1.49027 & 0.0473 \\
\hline PCGDP does not Granger Cause SEE & & 2.99362 & 0.0253 \\
\hline TEE does not Granger Cause PCGDP & 30 & 3.30420 & 0.0174 \\
\hline PCGDP does not Granger Cause TEE & & 0.82226 & 0.0340 \\
\hline
\end{tabular}

Source: Eview Computation, 2018.

Table 5 shows the Granger Causality tests at lag 7. The test was carried out by ensuring that all variables are stationary. The results that bi-directional relationships exist between total education expenditure and economic growth, all levels of education expenditures and economic growth in Nigeria. Since the p-values are less than 5\%, we reject the null hypothesis of no causality and accept the alternative hypothesis that causality runs from education spending to economic growth and vice versa line with Omojimite (2010).

The structural stability tests are presented in figure VII and Figure VIII. Both CUSUM test and CUSUM Square show that the model is stable and there is no structural change in the coefficients as vector of the coefficients remain constant all through the period because the blue lines are between the red lines at 5\% level of significance; hence we accept the null hypothesis of no structural change in the coefficients.

Structural Stability Tests Results

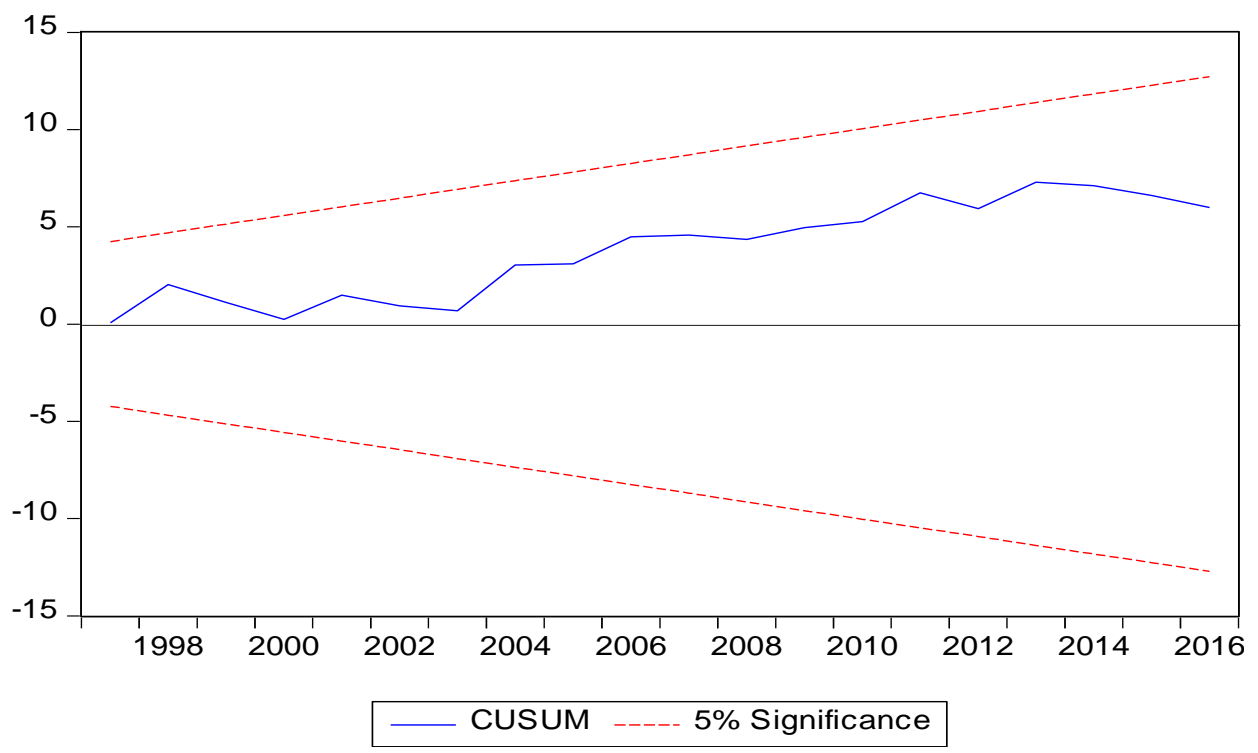

Figure 7. CUSUM Tests 


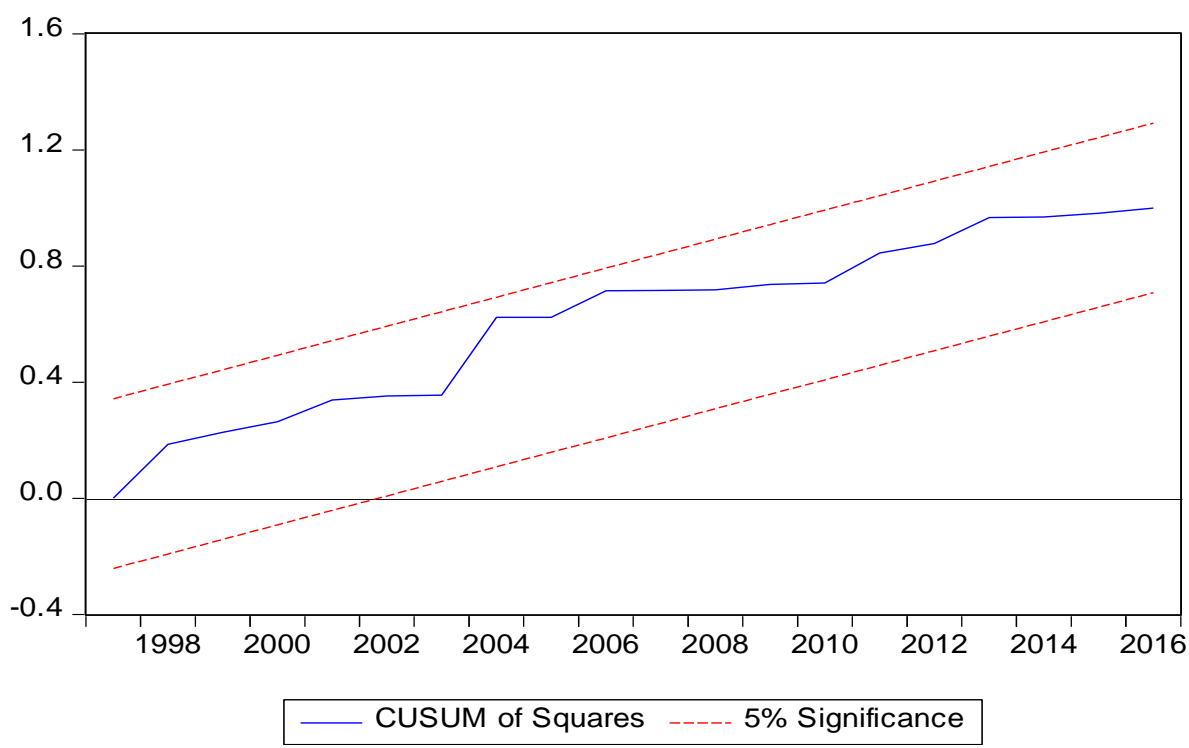

Figure 8. CUSUM Square Tests

\section{Conclusion and Policy Recommendations}

A significant body of literature has examined the correlation between education expenditure and economic growth in developing countries (See Kirian 2013; Lawanson, 2009; Dauda, 2010; Mercan and Sezer, 2014; Mitchell, (2005), Yildirim et al. 2011; Gisore et al. 2014; Jaiyeoba 2015; Nonetheless, results of empirical investigations remain inconclusive, and outcomes of recent studies show that the contribution of education expenditure to economic growth could be ambiguous (Rankaduwa et al. 2017). Increasing education expenditure may be suitable for economic growth. Still, analysis on the impact of education expenditure on economic growth could be better appreciated when education expenditure is disaggregated into different levels to ascertain which level exert much better impact on economic growth for appropriate policy direction.

This research work analysed the impact of government expenditure on education on the economic growth of Nigeria between 1980 and 2018. Specifically, to provide an understanding of the actual growth impact of government expenditure on education. Second, to x-ray which level of education expenditure has more footprint on economic growth in Nigeria. Third and final, to examine the feedback effects of economic growth on education spending in Nigeria. The results that originated from this study validated the positive stance of empirical studies like Kirian (2013), Lawanson, (2009) and Dauda, (2010), among others. This implies that, for Nigeria to experience better economic growth performance, deliberate policy action must be taken towards increasing budgetary allocation to Education. This is fundamental given the implications outcomes on development challenges facing Nigeria

Also, the study throws its weight behind disaggregated education expenditure- growth analysis as this deepens the frontier of knowledge and provides a fillip for policy direction. As revealed in this study, spending on all level of education has a positive impact on economic growth. However, tertiary education has a more significant effect on economic growth than primary and secondary education. Therefore, if government intent is to increase the level of economic growth in Nigeria, it must allocate more funds to tertiary education, followed by secondary and primary.

More so, as unearthed in this study, there is insufficient and inequality in the amount allocated to primary education annually in Nigeria. The disparity may not be unconnected with constitutional provision given that primary education is the responsibility of the state government with limited resources compared to the federal government. Secondary and tertiary education receive more than four times of public resources as much as primary education; an indication that primary schools are starved of financing. Notwithstanding the impact of tertiary education on economic growth, the need to increase budgetary allocation to education at all levels is sacrosanct because they all have the potential of contributing to economic growth. The importance of education expenditure at all levels should not be trivialised, given the complementary and symbiotic relationships that exist among them. In 2018 declaration of the state of emergency on education in Nigeria, the Federal Government has proposed $15 \%$ annual budgetary allocation to funding education at all levels. While this is laudable though 
implementation yet to commence, Government should as a matter of priority translate the proposal into policy action. This study also recommends that primary school funding should not be left in the hands of the state government alone as it is the foundation of education. Again, all other conditioning variables like heath and capital priority should be accorded in economic growth policies as they have been found to contribute positively to economic growth (see Acemoglu and Johnson, 2007 and Lorentzen et al., 2008).

Again, health is a crucial component of human capital. In this, health expenditure is used as a controlled variable. The impact of health on economic growth cannot be neglected as doing so could be at the peril not only on the economy but also on the effect of education on the economy given the complementary relationships between education and health. Therefore, Nigeria should take intentional policy actions to increase the amount of government expenditure on health. This also fundamental given the implication of health on the realization of the sustainable goal of no poverty in 2030.

Also, the bi-causal relationships between economic growth and all levels of education imply that education expenditure has the potential to influence economic growth. This is a motivation to increase budgetary allocation to education. However, tertiary education should be given the attention given its impact on economic growth, as revealed in this study. Similarly, economic growth has the potential of enhancing the amount of more available for investment in Education. This is also an important motivation for the government to take the issue of economic growth serious because Economic growth has the potential of creating better employment opportunities for the citizens and more tax revenue for the government. Increase in tax revenue implies more money for budgetary allocation to education. Therefore, policies aimed at diversifying and broadening the Nigerian economy be rekindled as economic growth have the potential of increasing education spending as shown by the feedback effects.

\section{References}

Acemoglu, D., \& Johnson, S. (2007). Disease and development: the effect of life expectancy on economic growth. Journal of Political Economy, University of Chicago Press, 115(6), 925-985. https://doi.org/10.1086/529000

Al-Samarrai, S. (2003). Financing primary education for all: public expenditure and education outcomes in Africa. Institute of Development Studies, University of Sussex, United Kingdom.

Babatunde, M. A., \& Adefabi, R. A. (2005). Long-Run Relationship between Education and Economic Growth in Nigeria: Evidence from the Johansen's Cointegration Approach. Paper Presented at the Regional Conference on Education in West Africa: Constraints and Opportunities. Dakar, Senegal, November 1st -2nd, 2005, Cornell University/ CREA/ Ministerede 1 'Education du Senegal.

Bakare, A. S. (2006). The Growth Implications of Human Capital Investment in Nigeria: An Empirical Study. Journal of Economics and Social Studies, University of Ado-Ekiti, 110-125.

Barro R. J. (2001). Human Capital and Economic Growth. American Economic Review, 91(2), 12-17. https://doi.org/10.1257/aer.91.2.12

Behrman, J. (1999). Labour Markets in Developing Countries in O. Ashenfelter and D. Card, Editors. Handbook of Labour Economics: 3B, 2101-2939. eBook ISBN: 9780080573755. https://doi.org/10.1016/S1573-4463(99)30029-8

Bratti, M., Bucci, A. \&Moretti, E. (2004). Demographic Trends, Human Capital and Economic Growth in Developing Countries: Theory and Evidence. University of Ancona Department of Economics, Ancona, Italy.

Coombs, P. H. (1985). The World Crisis in Education: The View from the Eighties. New York: Oxford University Press.

Dauda, R. O. S. (2010). Investment in Education and Economic Growth in Nigeria: An Empirical Evidence. International Research. Journal of Finance and Economics, 55. Euro Journals Publishing, Inc. 2010. Retrieved from http://www.eurojournals.com/finance.htm

Dauda, R.O. S. (2009). Investment in Education and Economic Growth in Nigeria: A Cointegration Approach. A paper presented at the $9^{\text {th }}$ Global Conference on Business and Economics held at University of Cambridge, UK.

Egunjobi, T. A. (2013). An econometric analysis of the impact of Corruption on economic growth in Nigeria. E3 Journal of Business Management and Economics, 4(3), 054-065. 
Engle, R., \& Granger, C. W. J. (1987). Co-integration and Error Correction: Representation, Estimation and Testing, Econometrica, 55(2), 251-276. https://doi.org/10.2307/1913236

Ewubare, D. B., \& Oghuagu, A. R. (2015). Capital Accumulation and Economic Growth in Nigeria "Endogenous Growth Approach. IOSR Journal of Economics and Finance (IOSR-JEF), 6(6), 49-64. Retrieved from www.iosrjournals.org

Ganger, C. W. J. (1981). Some Properties of Time Series Data and Their Use in Econometric Model Specification. Journal of Econometrics, 16, 121-130. https://doi.org/10.1016/0304-4076(81)90079-8

Gisore, N., Kprop, S., Kalio, A., \& Ochieng, J. (2014). Effect of Government Expenditure On Economic Growth In East Africa: A Disaggregated Model. European Journal of Business and Social Sciences, 3(8), 289-304. Retrieved from http://www.ejbss.com/recent.aspx-/

Glewwe, P. (2002). Schools and Skills in Developing Countries: Education Policies and Socioeconomic Outcomes. Journal of Economic Literature, 40(2), 436-482. https://doi.org/10.1257/jel.40.2.436

Glewwe, P. W., \& Muralidharan, K. (2016). Improving Education Outcomes in Developing Countries: Evidence, Knowledge Gaps, and Policy Implications. In S. Machin, L. Woessmann, \& E. A. Hanushek (Eds.), Handbook of the Economics of Education, 2016 (pp. 653-743). (Handbook of the Economics of Education; Vol. 5). Elsevier. https://doi.org/10.1016/B978-0-444-63459-7.00010-5

Glewwe, P., Maiga, E., \&Zheng, H. (2014). The Contribution of Education to Economic Growth: A Review of the Evidence, with Special Attention and an Application to Sub-Saharan Africa. https://doi.org/10.1016/j.worlddev.2014.01.021

Granger, C. W. J. (1969). Investigating Causal Relations by Econometric Models and Cross Spectral Method. Econometrica, 37(3), 424-438. https://doi.org/10.2307/1912791

Grant, C. (2017). The contribution of education to economic growth. Institute of Development Studies, Department of International Development, UK.

Gupta, M. R., \&Chakraborty, B. (2004). Human Capital Accumulation and Endogenous Growth in a Dual Economy. Hitotsubashi Journal of Economics, 47(2), 169-195.

Gylfason, T., \& Zoega, T. (2003). Education, Social Equality and Economic Growth: A View of the Landscape. CESifo Economic Studies, 49, 557-579. https://doi.org/10.1093/cesifo/49.4.557

Iheanacho, E. (2016). The Contribution of Government Expenditure on Economic Growth of Nigeria Disaggregated Approach. Int J Econ Manag Sci, 5, 369. https://doi.org/10.4172/2162-6359.1000369

Kirian, B. (2013). Testing the impact of educational expenditures on economic growth: new evidence from Latin American countries. Retrieved December 4, 2018, from https://link.springer.com/article/10.1007/s11135-013-9828-2

Lawanson, O. I. (2009). Human Capital Investment and Economic Development in Nigeria: The Role of Education and Health. Oxford Business \& Economics Conference Program ISBN: 978-0-9742114-1-1.

Lorentzen, P., McMillan, J., \& Wacziarg, R. (2008). Death and development. Journal of Economic Growth, 13, 81-124. https://doi.org/10.1007/s10887-008-9029-3

Lucas, R. E. (1988). Mechanics of economic development. Journal of Monetary Economics, 22(1), 3-42. https://doi.org/10.1016/0304-3932(88)90168-7

Mercan \& Sezer (2014). The Effect of Education Expenditure on Economic Growth: The Case of Turkey. Procedia - Social and Behavioral Sciences, 109(8), 925-930. https://doi.org/10.1016/j.sbspro.2013.12.565

Mitchel, J. D. (2005). The Impact of Government Spending on Economic Growth. Retrieved from www.heritage.org

Mwangi, M., \& Kariuki, S. (2015). Factors Determining Adoption of New Agricultural Technology by Smallholder Farmers in Developing Countries. Journal of Economics and Sustainable Development, 6(5).

Nwankwo, O. F. (2014). Impact of Corruption on Economic Growth in Nigeria. Mediterranean Journal of Social Sciences, 5(6). https://doi.org/10.5901/mjss.2014.v5n6p41

OECD/UIS, (2003). Financing Education Investments and Returns. Analysis of the World Education Indicators 2002 Edition.

Oketch, M., McCowan, T., \& Schendel, R. (2014). The Impact of Tertiary Education on Economic Development. 
Institute of Education University of London. Retrieved from http://r4d.dfid.gov.uk/

Okorie, G. C. (2014) Finance, Investment and Economic Growth: The Nigerian Experience. Retrieved August 28, 2017, from http://rassweb.org/admin/pages/ResearchPapers

Olokoyo, F. O. (2012). Foreign Direct Investment and Economic Growth: A Case of Nigeria Bvimsr's. Journal of Management Research, 4(1).

Omojimite, B. U. (2010) Education and Economic Growth in Nigeria: A Granger Causality Analysis. African Research Review, 4(3a) 90-108. https://doi.org/10.4314/afrrev.v4i3.60158

Omojimite, B. U. (2012) Public Education and Defence Spending in Nigeria: Implications for Economic Growth. Journal of Educational and Social Research, 2(1).

Oyelekan, B., Kareem, R., \& Bakare, H. (2015) Effects of Inflation Rate on Economic Growth in Nigeria Retrieved August 28, 2017 from www.iiste.org

Paganetto, L., \& Scandizzo, P. L. (2003). The Role of Education and Knowledge in Endogenous Growth, in Finance, Research, Education and Growth. Luigi Paganetto and Edmund Phelps, Palgrave, New York. https://doi.org/10.1057/9781403920232

Pedroni, P. (1999). Critical values for cointegration tests in heterogeneous panels with multiple regressors. Oxford Bulletin of Economics and Statistics, 61(4), 653-670. https://doi.org/10.1111/1468-0084.61.s1.14

Rankaduwa, W., Haider, A., \& Cooray, N. S. (2017). Education Expenditure and Economic Growth Under Decentralization: An Empirical Study of Sri Lanka and Canada. Decentralization and Development of Sri Lanka Within a Unitary State pp 311-327. https://doi.org/10.1007/978-981-10-4259-1_14

Romer, P. M. (1986) Increasing returns and long-run growth. Journal of Political Economy, 94(5), 1002-1037. https://doi.org/10.1086/261420

Romer, P. M. (1990). Endogenous Technological Change. Journal of Political Economy, 98, 571-5102. https://doi.org/10.1086/261725

Roser, M., \& Ortiz-Ospina, E. (2020). Financing Education. Published online at OurWorldInData.org. Retrieved from https: //ourworldindata.org/financing-education

Sargan, J. D. (1984). Wages and Prices in the United Kingdom: A Study in Econometric Methodology. In K. F. Wallis \& D. F. Hendry, (Eds.), Quantitative Economic and Econometric Analysis, Basil Blackwell, Oxford, $U . K$.

Schultz, T. P. (1999). Health and Schooling Investments in Africa. Journal of Economic Perspectives, 13(3), 67-88. https://doi.org/10.1257/jep.13.3.67

Schultz, T. P. (2002). Why Governments Should Invest More to Educate Girls. World Development Journal, 30 , 207-225. https://doi.org/10.1016/S0305-750X(01)00107-3

Sen, A. (1999). Development as Freedom. International Journal of Epidemiology, 30(4), 907-908, https://doi.org/10.1093/ije/30.4.907-a

Shettima, M. B. (2017). Impact of SMEs on Employment Generation in Nigeria. IOSR Journal of Humanities And Social Science (IOSR-JHSS), 22(9), 43-50.

Shrestha, M. B., \& Bhatta, G. R. (2017). Selecting an appropriate methodological framework for time series data analysis. The Journal of Finance and Data Science, 4(2), 71-89. https://doi.org/10.1016/j.jfds.2017.11.001

Shuaib, I. M., \& Ndidi, D. E. (2015). Capital Formation: Impact on The Economic Development of Nigeria. European Journal of Business, Economics and Accountancy, 3(3), 2015.

Sims, C. (1972). Money, Income, and Causality. American Economic Review, 62, 540-552.

Solow, R. M. (1956). A Contribution to the Theory of Economic. The Quarterly Journal of Economics, 70(1), 64-95. https://doi.org/10.2307/1884513

Strauss, J., \& Duncan, T. (1995). Health, Nutrition, and Economic Development. Journal of Economic Literature, 36(2), 766-817.

Turruam, J. T., Chiawa, M. A., \& Abur, C. C. (2014). Cointegration Analysis of Public Expenditure on Tertiary Education and Economic Growth in Nigeria. CBN Journal of Applied Statistics, 5(2).

Ugochukwu, U. S., \& Chinyere, U. P. (2013). The Impact of Capital Formation on the Growth of the Nigerian Economy. Research Journal of Finance and Accounting, 4(9), 1-8. 
UNDP. (1990). Human Development Report 1990. New York: Oxford University Press. k: Oxford University Press.

United Nations. (2018). Achieving Sustainable Development Goals in the Least Developed Countries. A compendium of Policy Options.

Urhie, E. S. (2013). Public Education Expenditure and Economic Growth in Nigeria: A disaggregated Approach. Journal of Empirical Economics, 3(6), 370-382

Usman, F. K., \& Adeyinka, O. B. (2019). Effect of Human Capital Development on Economic Growth of ECOWAS Member States. Advances in Sciences and Humanities, 5(1), 27-42. https://doi.org/10.11648/j.ash.20190501.14

Wang, M., \& Wong, S. M. C. (2011). Foreign Direct Investment, Education, and Economic Growth: Quality Matters. Atlantic Economic Journal, 39(2), 103-115. https://doi.org/10.1007/s11293-011-9268-0

Yildirim, N., Deniz, H., \& Hepsag, A. (2011). Do public education expenditures really lead to economic growth? Evidence from Turkey. International Research Journal of Finance and Economics, 65, 13-24.

\section{Copyrights}

Copyright for this article is retained by the author(s), with first publication rights granted to the journal.

This is an open-access article distributed under the terms and conditions of the Creative Commons Attribution license (http://creativecommons.org/licenses/by/4.0/). 